Reprod. Nutr. Dévelop., 1987, 27 (3), 627-639.

\title{
Maturation of luteinizing hormone-releasing hormone (LHRH) and somatostatin (SRIF) neuronal systems in the hypothalamus of growing ewe lambs
}

Jolanta POLKOWSKA, M.-P. DUBOIS (*), M. JUTISZ (**)

Institute of Animal Physiology \& Nutrition.

Polish Academy of Sciences, 05-110 Jablonna, Poland.

(*) Station de Physiologie de la Reproduction, I.N.R.A., Nouzilly, France.

(**) Laboratoire des Hormones Polypeptidiques, C.N.R.S., Gif-sur-Yvette, France.

Summary. Using the immunoperoxidase method, neurons containing luteinizing hormone-releasing hormone (LHRH) and somatostatin (SRIF) were identified in the hypothalamus of growing ewe lambs between 3 days and 16 weeks of age. Both peptidergic neuronal systems were well developed in the early postnatal period. The centres producing $\mathrm{LHRH}$ were found to be situated in the anterior region of the hypothalamus and preoptic area. Immunoreactive (ir) LHRH perikarya in growing lambs were readily stained by the various anti-LHRH antibodies used and they were generally more numerous in young animals than in foetuses and adults. The concentration of irLHRH material stored in the median eminence (ME) increased with lamb age, reaching a maximum around 12 weeks of age. The centre producing somatostatin, situated in the anterior periventricular area of the hypothalamus, did not develop before the postpartum period. The irSRIF material in the ME was greatly depleted during the first neonatal days but regained its former level by 8 weeks of age. From 10 to 16 weeks of age, these stores in the ME were again depleted. The results show that the two neuronal systems investigated developed in a different way in the growing lamb. The secretory activity of these systems changed during subsequent periods of growth. The importance of these events in the processes of body growth and reproductive system maturation are still to be determined.

\section{Introduction.}

Radioimmunological investigations of the hypothalamo-pituitary unit of sheep show that the activity of this unit begins in the early prenatal period (Gluckman et al., 1979a, b ; Sklar et al., 1981). In a previous work (Polkowska, 1986), we reported that the hypothalamic hormones which control gonadotrophin and somatotrophin release appear in the hypothalamus of foetal sheep as early as the beginning of the second part of pregnancy. However, the evolution of the LHRH and SRIF neuronal systems during the period the ewe reproductive system is growing and developing, has not been studied previously. Only the activity of the 
pituitary-gonadal system in growing ram lambs has been reported (Collu et al., 1983). It has been shown that this system becomes active in rams after parturition (Foster et al., 1972). The sensitivity of the pituitary gland to LHRH stimulation has been demonstrated in foetal (Foster, 1974) and newborn (Foster et al., 1972 ; Mueller et al., 1981) sheep.

In order to better understand the role of the hypothalamus in the control of pituitary hormones during development in the lamb, we investigated the maturation of two hypothalamic neuronal systems which might take part in growth and sexual maturation.

\section{Material and methods.}

The experiments were carried out on 25 Merino ewe lambs between 1 and 16 weeks of age. Nine groups of lambs of various ages were studied (table 1).

The lambs were slaughtered, decapitated and their brains immediately perfused via both internal carotid arteries with $0.1 \mathrm{M}$ phosphate buffered saline (PBS) and subsequently with paraformaldehyde-picric acid buffered with $0.1 \mathrm{M}$ PBS (Zamboni and De Martino, 1967). The hypothalami were dissected $30 \mathrm{~min}$ after the start of perfusion and postfixed for $72 \mathrm{~h}$ by immersion in Bouin fixative with trichloroacetic acid (Halmi, 1952). The preparations were washed with $0.01 \mathrm{M}$ PBS, dehydrated in graded alcohols and embedded in paraplast (Serva). The hypothalami were cut in the coronal planes into $5-\mu \mathrm{m}$ sections. For histological and topographical studies, every 20th section was stained by the method of Klüver and Barrera (1955). The hormones were localized by the peroxidase labelled antibody method (Nakane and Pierce, 1966). The following antisera were used : antiLHRH (ref. 1076 and ref. 743) prepared by Dr. A. Arimura, Tulane University (King and Millar, 1980), dilution 1:1000; anti-LHRH (ref. H-6) prepared by Dr.

\section{TABLE 1}

Age and number of lambs studied.

\begin{tabular}{|c|c|c|}
\hline Group & Age & Number \\
\hline 1 & 3 to 5 days & 3 \\
\hline 2 & 2 weeks & 3 \\
\hline 3 & $4 》$ & 3 \\
\hline 4 & $6 》$ & 2 \\
\hline 5 & $8 》$ & 3 \\
\hline 6 & 10 & 2 \\
\hline 7 & $12 »$ & 3 \\
\hline 8 & $14 》$ & 3 \\
\hline 9 & $16 》$ & 3 \\
\hline
\end{tabular}

FIG. 1. - Localization of irLHRH perikarya. a. horizontal wing of DBB. $\times 35$; b. vertical wing of DBB. $\times 35 ;$ c. OVLT. $\times 70$; d. lateral preoptic nucleus. $\times 88$.

FIG. 2. - Various forms of irLHRH perikarya. a. cells with two short recesses (medial preoptic nucleus) ; b. a cell with one long recess (lateral preoptic nucleus) ; c. a cell with one short recess (nucleus supraopticus); d. perikarya LHRH staining with the intensification method (OVLT). $\times 224$. 
G. Fink, MRC, Edinburgh (unpublished), dilution $1: 2000$; anti-LHRH (ref. 19900), anti-LHRH (ref. 8516) and anti-SRIF (ref. 19608) prepared by Dr. M.-P. Dubois, I.N.R.A., Nouzilly (Barry et al., 1973 ; Dubois and Barry, 1974), dilution 1: 1000 ; anti-LHRH (ref. $\mathrm{H}-16$ ) prepared in the Medical School at Pecs, Hungary (Merchenthaler et al., 1982), dilution $1: 3000$.

The reaction with the first antibody lasted $96 \mathrm{~h}$ at $4{ }^{\circ} \mathrm{C}$. Peroxidase-labelled ovine anti-rabbit gamma globulin (Institut Pasteur, Paris), used as the second antibody at a dilution of $1: 40$, was incubated with the preparation for $2 \mathrm{~h}$ at room temperature. All antibodies were diluted in $0.01 \mathrm{M}$ PBS containing $0.1 \%$ of bovine serum albumin (BSA). Before reaction, the preparations were washed with $0.01 \mathrm{M}$ PBS containing $1 \%$ of normal ovine serum and $0.01 \mathrm{M}$ PBS containing $1 \%$ of hydrogen peroxide. The horseradish peroxidase was localized with 3.3 diaminobenzidine tetrachloride (Sigma) and $0.005 \%$ of hydrogen peroxide for $6 \mathrm{~min}$ at room temperature according to Graham and Karnovsky (1966). A part of the material was also stained by the intensification method of Liposits et al. (1983). The inhibition of anti-hormone serum with its homologous antigen was used as control reaction. The cross-reactivities of anti-LHRH serum were blocked by $10 \mu \mathrm{g}$ of LHRH (UCB, Belgium) or by $50 \mu \mathrm{g}$ of SRIF (Cyclic Clinic Midy) per $1 \mathrm{ml}$ of antiserum, diluted $1: 500$.

\section{Results.}

Luteinizing hormone-releasing hormone. - The best staining reaction was obtained using antibody (ref. 19900) generated against sequence 2-10 of the peptide. Perikarya synthesizing LHRH were found in all age groups investigated but the highest number was observed in material from 12 and 14-week old animals. The perikarya were localized exclusively in the anterior regions of the hypothalamus and in the preoptico-septal area. Maximal cell concentration was observed in the area of the diagonal band of Broca (DBB) and the area preoptica (AP) in the immediate vicinity of the organum vasculosum of the lamina terminalis (OVLT) and the recessus supraopticus (figs 1c, $2 \mathrm{~d}$ ). The cells in the DBB were seen in the vertical as well as in the horizontal wings (figs. 1a, 1b). In the AP they were scattered in the medial preoptic nucleus (fig. 2a), lateral preoptic nucleus (figs. 1d, 2b) and the anterior part of the nucleus preopticus periventricularis. Occasionally, irLHRH perikarya could be distinguished in other parts of the hypothalamus, e.g. in the area of the supraoptic nucleus (fig. 2c), but they were not found in the region of the medial basal hypothalamus. The nerve terminals situated in the OVLT and the ME containing irLHRH material displayed a very strong immunoreaction with all the anti-LHRH antibodies used. The irLHRH material observed in the OVLT was scarce and remained stable as the lambs aged, whereas the accumulation of irLHRH material in the ME increased progressively with animal age. This phenomenon was observed in the anterior (figs. 3a, 3d) as well as in the central part of the ME (figs. 4a, 4d).

FIGS. 3 and 4. - Frontal sections of the ME: anterior part (3), central part (4). Note the increasing concentration of irLHRH material with lamb age. a. 3 days of age ; b. 2 weeks; c. 10 weeks ; d. 14 weeks. FIG. $3: \times 70 ;$ FIG. $4: \times 28$. 



3b
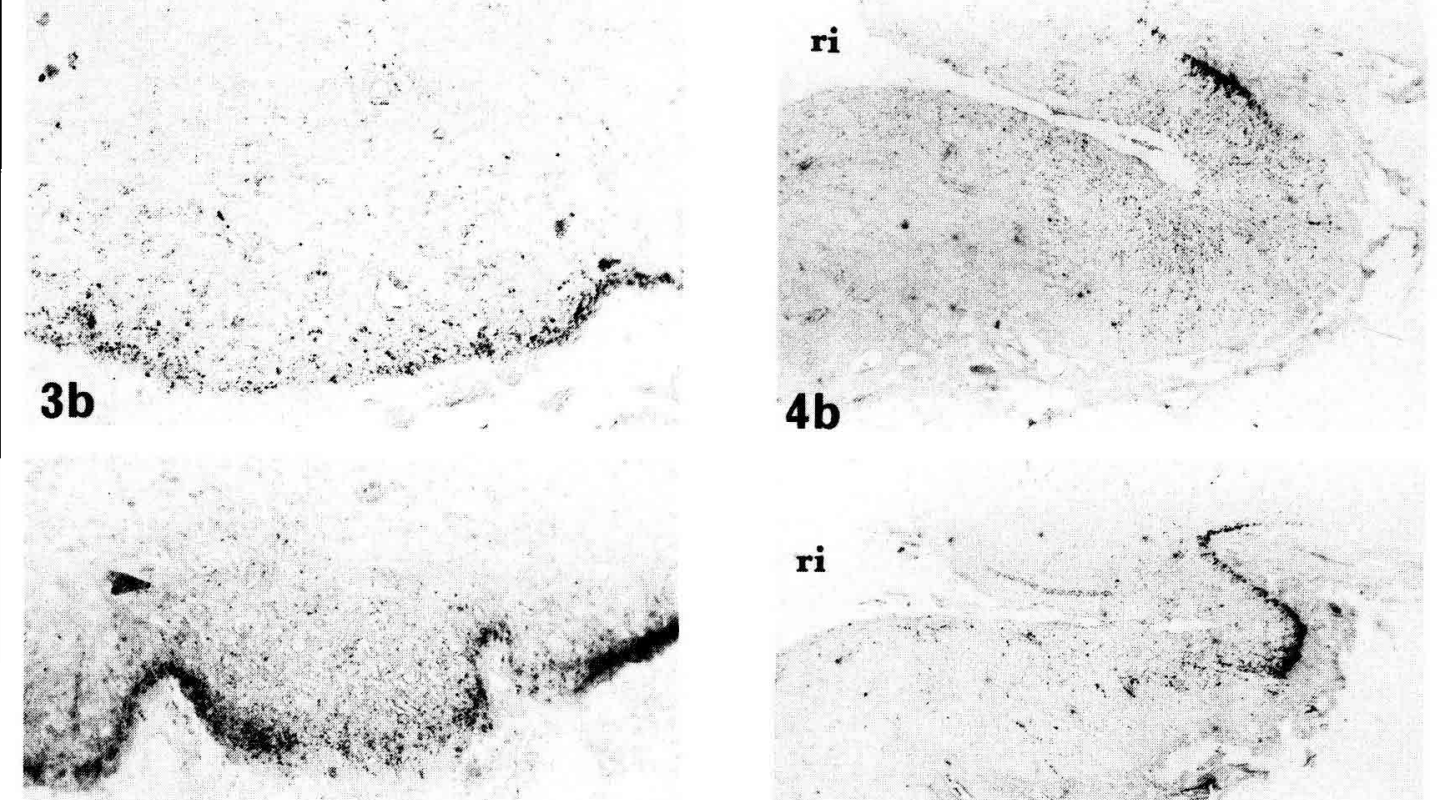

3c
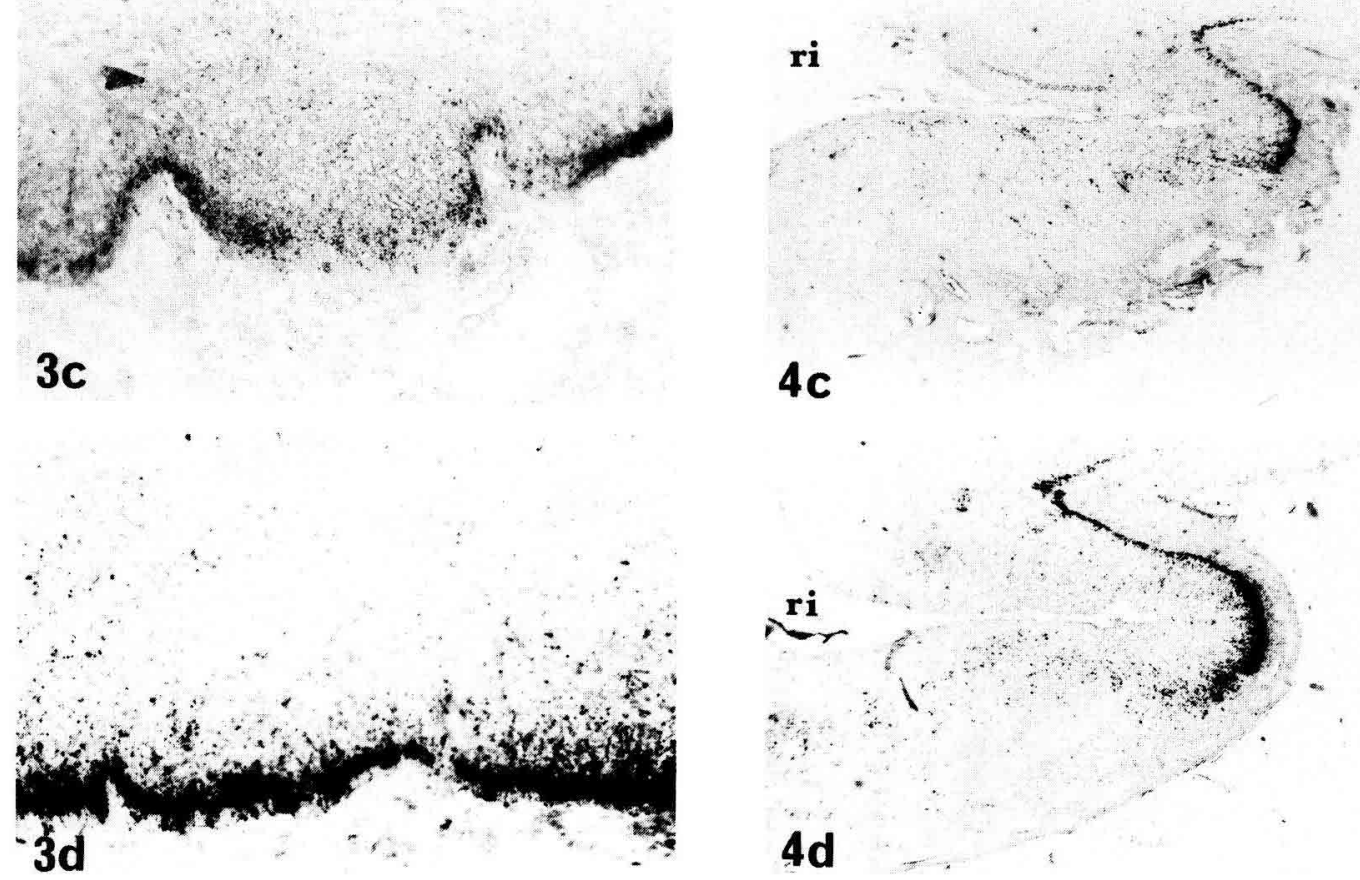
Somatostatin. - Two different populations of irSRIF perikarya were found in the forebrain of growing lambs, one in the preopticoseptal area and the other in the anterior hypothalamus. The cells of the first population were elongated with a centrally situated nucleus and a few short dendrites. These cells were larger than the SRIF perikarya of the second population, but smaller than the ir-neurophysin cells (figs. 7a, 7c). With the exception of islands of closely associated cells located in the lateral preoptic nucleus (figs. 5a, 5b), the cells of the preopticoseptal area were widespread throughout the septum with a greater number of perikarya in the vertical wing of the DBB (fig. $5 \mathrm{c}$ ) and the nucleus accumbens. They were more numerous in groups of animals from 1 to 10 weeks of age and rather rare in older animals 10 to 16 weeks old.

The second population of SRIF perikarya, found in the region of the anterior hypothalamus, were co-localized to some extent with the neurophysin perikarya, i.e. in the suprachiasmatic nucleus and the anterior periventricular band of the paraventricular nucleus (figs. $6 a, 6 \mathrm{~d}$ ). The density of immunostaining by anti-SRIF antibody was very weak in these cells, so immunogold intensification was used to better visualize them. The SRIF perikarya were small and oval with an eccentric nucleus and one short dendrite. Their number increased with lamb age, being moderate in the postpartum group and highest in the hypothalami of 14-week old animals. Although the irSRIF fibres were scattered throughout the entire forebrain, most of them were found in dense clusters within two areas situated in the ventromedial nucleus and in the anterior pericommissural area (figs. 8a, 8b). No perikarya were present in the vicinity of these bundles. IrSRIF material situated in the nerve terminals of the central part of the ME and infundibulum was abundant (figs. 10a, 10b) in all age groups, except during the first 3 to 5 days post partum (figs. 9a, 9c). From 10 weeks of age, there was some evidence of a reduction of the SRIF stores in the central part of the ME. The depletion of stain intensity was most evident between 10 and 16 weeks of age (figs. 11a, 11c).

\section{Discussion.}

The present study demonstrates that localization of irLHRH perikarya in growing lambs is the same as in foetal and adult sheep (Polkowska, 1981; Lehman et al., 1984 ; Advis et al., 1985 ; Polkowska, 1986). The presence of irLHRH perikarya in the rostral part of the hypothalamus and the preoptico-septal

FIG. 5. - Localization of irSRIF perikarya in the preoptico-septal region of the brain. a. a group of cells in the lateral preoptic nucleus. $\times 28 ; b$. at high magnification. $\times 224 ; c$. dispersed cells in the DBB. $\times 70$.

FIG. 6. - Periventricular area of the hypothalamus. a. ir-neurophysin cells. $\times 70$; b. irSRIF cells in the same region. $\times 70 ; c$. higher magnification of the group marked by an asterix. $\times 224$; d. irSRIF cells in the suprachiasmatic nucleus. $\times 70$.

FIG. 7. - IrSRIF cells in (b) the paraventricular nucleus, (c) the area preoptica. (a) Comparison with ir-neurophysin cells. Notice the different shape and size of these perikarya. $\times 740$.

FIG. 8. - IrSRIF fibres in (a) the ventromedial nucleus, (b) the anterior pericomissural area. $\times 180$. 
area of the brain has been also shown by Lehman et al. (1984) and Advis et al. (1985). Contrary to our present data, Dees et al. (1981) found LHRH perikarya mainly in the ventromedial hypothalamus of sheep. In comparison with the foetal period (Polkowska, 1986), LHRH immunoreactivity seemed to intensify in postnatal life. This intensification was manifested by a higher number of irLHRH perikarya and increased irLHRH stores in the nerve terminals of the ME of growing lambs. One possible explanation of these observations might be the increased secretory activity of LHRH-producing neurons. This activity, associated with storage of the hormone in the nerve terminals of the $M E$, reached a maximum around 12 weeks of age and remained at that level until at least 16 weeks. These data suggest that the hypothalamo-pituitary axis is activated as the lamb ages, as reflected by changes in plasma LH levels. Such hormonal changes have been found up to now only in ram lambs. It has been shown that plasma LH rises progressively from birth, reaching a maximum between 8 and 12 weeks of age (Cotta et al., 1975) and that the frequency of LH pulses increases between 1 and 8 weeks of age (Foster et al., 1978). The pituitary gland gains the ability to secrete $\mathrm{LH}$ in response to LHRH during the first few weeks after birth (Galloway and Pelletier, 1974 ; Lee et al., 1976), and the total quantity of LH released by exogenous LHRH increases after 12 weeks of age (Galloway and Pelletier, 1974). These changes might reflect a maturation of the central mechanism, i.e. the LHRH neuronal system governing LH secretion during ewe aging.

The irSRIF perikarya were localized in the preoptico-septal area and the anterior periventricular part of the hypothalamus, so growing lambs are similar to humans, monkeys (Filby and Gross, 1983) and rats (Alpert et al., 1976 ; Krisch, 1978 ; Dierickx and Vandesande, 1979). Periventricular localization in sheep includes the localization of neurophysin within the boundaries of the suprachiasmaticus and the anterior periventricular part of the paraventricular nucleus. Deafferentation experiments in rats have shown that most of the SRIFcontaining neurons originating in these areas leave the perikarya in a lateral direction, form loops across the lateral hypothalamus, and enter the mediobasal hypothalamus at the ME level (Makara et al., 1983). This could explain why we observed a high number of SRIF neurons in the ventromedial nucleus. SRIFcontaining fibres in the vicinity of the anterior commissure have also been reported in rhesus monkeys and humans (Filby and Gross, 1983) and are thought to be projections from cell bodies situated in the preoptico-septal region. We observed that various somatostatin-producing centres appear and disappear in the sheep brain throughout the foetal period (Polkowska, 1986). The centre situated in the anterior periventricular area of the hypothalamus and invisible until the last

FIG. 9. - Frontal sections of the central part of the ME. IrSRIF material. a. 1 day of age ; b. 8 weeks ; c. 14 weeks : $\times 88$.

FIG. 10. - Distribution of irSRIF material in (a) the central part of the ME, (b) the pituitary stalk. 14 weeks of age. $\times 28$.

FIG. 11. - Different degrees of reduction of irSRIF material in the ME of 16-week old lambs. $\times 88$. 
days of pregnancy, became prominent in growing lambs. Considering that this centre supplies somatostatin mostly to the $M E$, these observations suggest that the importance of somatostatin as an hypophysiotrophic hormone increases with age; and that this system matures after parturition.

The population of somatostatin perikarya, found in the preoptico-septal area of the brain, differed morphologically from the paraventricular one ; its function in sheep has not been determined yet. It has been suggested that extrahypothalamic somatostatin neurons in rats are independent from the hypothalamic system and that somatostatin produced by these neurons acts as a neurotransmitter or a neuromodulator rather than a hypophysiotrophic hormone (Krisch, 1980). It is generally agreed that somatostatin is one of at least two factors in the hypothalamus which modulate somatic growth by controlling growth hormone (GH) secretion. The inhibitory mechanism mediated by hypothalamic SRIF probably develops in ruminants during the foetal period. In the sheep foetus, exogenous somatostatin suppresses plasma GH levels (Gluckman et al., 1979a, b), indicating the presence of SRIF receptors in the foetal pituitary. Somatostatin appears in the sheep hypothalamus in the second part of pregnancy (Polkowska, 1986). The dramatic decrease in irSRIF content in the ME, observed in neonates, might be associated with a sudden fall in plasma GH during parturition (Wallace et al., 1973). SRIF is a potent inhibitor of GH under stress (Kasting et al., 1981), so the depletion of irSRIF material in the ME stores around the neonatal period might reflect the rapid release of this peptide during parturition.

Little is known of the role of somatostatin during growth in lambs. From the results presented here it is evident that the SRIF neuronal system is mature by 8 to 10 weeks of age. The reduction of SRIF stores in the ME during this period could be interpreted as a rapid release of this hormone into the capillary system of the primary plexus. The subsequent increase in the level of SRIF material between 10 and 16 weeks of age presumably reflects further maturation of the $\mathrm{GH}$ secretory mechanism. Mean $\mathrm{GH}$ concentration tends to decline with age (Klindt et al., 1985) and remain at a level similar to that in adults or about one-twenthieth of that in foetuses (Basset et al., 1970). Immunization of lambs against somatostatin at 27 to 103 days of age removes the inhibitory effect of SRIF and increases growth by augmenting GH secretion (Spencer et al., 1983). These data support our immunocytochemical results indicating the existence of an inhibitory SRIF system in the hypothalamus and its role in controlling lamb growth.

Reçu en juin 1986.

Accepté en janvier 1987.

Acknowledgements. - The authors wish to thank Dr. G. Sétáló (Medical Academy of Pecs), Dr. A. Arimura (Tulane University) and Dr G. Fink (MRC, Edinburgh) for the antisera to LHRH. We also wish to thank Mrs Ewa Skrzeczynska for her skillful technical assistance and Dr. G. Martin and Mrs A. Daifuku for correcting the English. This work was supported by grant MR-II.10 from the Ministry of Science, High Education and Technics, Poland, and by a grant from the World Health Organization, Human Reproduction Unit, through its Small Supplies Program. 
Résumé. Maturation des neurones produisant du LHRH (luteinizing hormone-releasing hormone) et du SRIF (somatostatine) dans l'hypothalamus d'agneaux femelles en croissance.

Des neurones contenant du LHRH (luteinizing hormone releasing hormone) et du SRIF (somatostatine) ont été identifiés au moyen de la méthode cytoimmunochimique à la peroxydase dans l'hypothalamus d'agneaux femelles, en période de croissance, âgés de 3 jours à 16 semaines. Les deux systèmes de neurones peptidergiques sont bien développés dès la période post-natale. Les centres producteurs de LHRH ont été identifiés dans la région antérieure de l'hypothalamus et dans l'aire préoptique. Les péricaryons immunoréactifs (ir) contenant du LHRH chez les agneaux en croissance sont facilement marqués par les différents anticorps anti-LHRH utilisés et sont généralement plus nombreux chez l'agneau que chez le fœetus de mouton ou le mouton adulte. La concentration de ir-LHRH dans l'éminence médiane augmente avec l'âge de l'animal et atteint son maximum aux environs de 12 semaines. Le centre producteur de somatostatine est situé dans l'aire périventriculaire antérieure de l'hypothalamus; il ne se développe pas avant la période post-natale. On observe une importante diminution du ir-SRIF dans l'éminence médiane durant les premiers jours de la vie, suivie par une reconstitution du stock jusqu'à la $8^{\circ}$ semaine après la naissance. Nos résultats montrent que les deux systèmes neuronaux étudiés chez l'agneau en croissance se développent d'une manière différente. L'importance de ces événements pour le processus de croissance corporelle et la maturation du système de reproduction, doit encore être confirmée.

\section{References}

ADVIS J. P., KULJIS R. O., DEY G., 1985. Distribution of luteinizing hormone-releasing hormone (LHRH) content and total degrading activity (LHRH-DA) in the hypothalamus of the ewe. Endocrinology, 116, 2410-2418.

ALPERT L. C., BRAWER J. R., PATEL Y. C., REICHLIN S., 1976. Somatostatinergic neurons in anterior hypothalamus : immunocytochemical localization. Endocrinology, 98, 255-258.

BARRY J., DUBOIS M. P., POULAIN P., 1973. LRF-producing cells of the mammalian hypothalamus. A fluorescent antibody study. $Z$. Zellforsch., 146, 351-366.

BASSET J. M., THORBURN G. D., WALLACE A. L. C., 1970. The plasma growth hormone concentration of the foetal lamb. J. Endocr., 48, 251-263.

COllu R., SAVOIE S., HAMEL R., GIBB W., DUCHARME J. R., 1983. Maturation of the hypothalamic-pituitary-gonadal axis in the male lamb: A review. Psychoneuroendocrinology, 8. 213-224.

COTTA Y., TERQUI M., PELLETIER J., COUROT M., 1975. Testostérone et LH plasmatiques chez l'agneau de la naissance à la puberté. C. R. Acad. Sci. (D) Paris, 280, 1473-1476.

DEES W. L., SORENSEN Jr A. M., KEMP W. M., McArthur M. H., 1981. Immunohistochemical localization of gonadotropin-releasing hormone $(\mathrm{GnRH})$ in the brain and infundibulum of the sheep. Cell Tiss. Res., 215, 181-191.

DIERICKX K., VANDESANDE F., 1979. Immunocytochemical localization of somatostatin-containing neurons in the rat. Cell Tiss. Res., 201, 349-359.

DUBOIS M. P., BARRY J., 1974. Répartition comparée de trois neurofacteurs hypothalamiques : LHRH; SRIF et neurophysine dans I'hypothalamus et l'éminence médiane. Etude en immunofluorescence. Ann. Endocrinol., 35, 663-664.

FILBY A. B., GROSS D. S., 1983. Distribution of immunoreactive somatostatin in the primate hypothalamus. Cell Tiss. Res., 233, 69-80.

FOSTER D. L., 1974. Regulation of gonadotropins during fetal and early postnatal development in the sheep. In M. G. FOREST, J. BERTRAND, Sexual endocrinology of the perinatal period. Colloques INSERM, vol. 32, 143-156.

FOSTER D. L., ROACH J. F., KARSCH F. J., NORTON H. W., COOK B., NALBANDOV A. V., 1972. Regulation of luteinizing hormone in the fetal and neonatal lamb. I. LH concentration in blood and pituitary. Endocrinology, 90, 102-111. 
FOSTER D. L., MICKELSON I. H., RYAN K. D., COON G. A., DRONGOWSKI R. A., HOLT J. A., 1978. Ontogeny of pulsatile luteinizing hormone and testosterone secretion in male lambs. Endocrinology, 102, 1137-1146.

GALLOWAY D. G., PELLETIER J., 1974. Influence of age on the pituitary response of male lambs to synthetic LH-RH injection. Horm. Metab. Res., 6, 241-246.

GLUCKMAN P. D., MUELLER P. L., KAPLAN S. L., RUDOLPH A. M., GRUMBACH M. M., 1979a Hormone ontogeny in the ovine fetus. I. Ovine growth hormone in mid-and late gestation. Endocrinology, 104, 162-166.

GLUCKMAN P. D., MUELLER P. L., KAPLAN S. L., RUDOLPH A. M., GRUMBACH M. M., 1979b. Hormone ontogeny in the ovine fetus. III. The effect of exogenous somatostatin. Endocrinology, 104, 974-978.

GRAHAM R. C., KARNOVSKY M. J., 1966. The early stages of absorbtion of injected horseradish peroxidase in the proximal tubules of mouse kidney. Ultrastructural cytochemistry by a new technique. J. Histochem. Cytochem., 14, 291-302.

HALMI N. S., 1952. Differentiation of two types of basophils in the adenohypophysis in the rat and mouse. Stain Technol., 27, 61-64.

KASTING N. W., MARTIN J. B., ARNOLD M. A., 1981. Pulsatile somatostatin release from the median eminence of the unanesthetized rat and its relationship to plasma growth hormone levels. Endocrinology, 109, 1739-1741.

KING J. A., MILLAR R. P., 1980. Comparative aspects of luteinizing hormone-releasing hormone structure and function in vertebrate phylogeny. Endocrinology, 106, 707-717.

KLINDT J., OHLSON D. L., DAVIS S. L., SCHANBACHER B. D., 1985. Ontogeny of growth hormone, prolactin, luteinizing hormone and testosterone secretory pattern in the ram. Biol. Reprod., 33, 436-445.

KLÜVER H., BARRERA B., 1955. A method for the combined staining of cells and fibers of the nervous system. J. Neuropath. clin. Neurol., 12, 400-407.

KRISCH B., 1978. Hypothalamic and extrahypothalamic distribution of somatostatin immunoreactive elements in the rat brain. Cell Tiss. Res., 195, 499-513.

KRISCH B., 1980. Differing immunoreactivity of somatostatin in the cortex and the hypothalamus of the rat. Cell Tiss. Res., 212, 457-464.

LEE W. W. K., CUMMING I. A., DE KRETSER D. M., FINDLAY J. K., HUDSON B., KEOGH E. J., 1976. Regulation of gonadotropin secretion in rams from birth to sexual maturity. II. Response of the pituitary-testicular axis to LH-RH infusion. J. Reprod. Fert., 46, 1-6.

LEHMAN M. N., SILVERMAN A. J., ROBINSON J. E., KARSCH F. J., 1984. Luteinizing hormonereleasing hormone (LHRH) pathways in the sheep brain during anestrus and the mid-luteal phase. 7-th Int. Congr. Endocrinol., 1-7 July, Quebec City, Abstr. p. 883.

LIPOSITS Z., LÁZÁR G., LENGVÁRI I., GÖRCS T., VIGH S., SCHALLY A. V., 1983. Silver intensification-DAB method. I. Detection of corticotropin releasing factor (CRF) synthesizing neuronal structures in the rat and frog brain. A light and electron microscopic study. 7-th Europ. Neurosci. Congr., Hamburg 1983.

MAKARA G. B., PALKOVITS M., ANTONI F. A., KISS J. Z., 1983. Topography of the somatostatin-immunoreactive fibers in the stalk-median eminence of the rat. Neuroendocrinology, 37, 1-8.

MERCHENTHALER I., GÖRCS T., SÉTÁLO G., 1982. Neurons containing luteinizing hormonereleasing hormone in the indusium griseum of the rat. Acta morphol. Acad. Sci. Hung., 30, $151-156$.

MUELLER P. L., SKLAR C. A., GLUCKMAN P. D., KAPLAN S. L., GRUMBACH M. M., 1981. Hormone ontogeny in the ovine fetus. IX. Luteinizing hormone and follicle-stimulating hormone response to luteinizing hormone-releasing factor in mid-and late gestation and in the neonate. Endocrinology, 108, 881-886.

NAKANE P. K., PIERCE G. B., 1966. Enzyme-labelled antibody preparation and application for antigen localization. J. Histochem. Cytochem., 14, 929-931.

POLKOWSKA J., 1981. Immunocytochemistry of luteinizing hormone-releasing hormone (LHRH) and gonadotropic hormones in the sheep after anterior deafferentations of the hypothalamus. Cell Tiss. Res., 220, 637-649. 
POLKOWSKA J., 1986. Ontogeny of luteinizing hormone-releasing hormone (LHRH) and somatostatin (SRIF) in the hypothalamus of the sheep. Folia histochem. cytobiol., 24, 195-199.

SKLAR C. A., MUELLER P. L., GLUCKMAN P. D., KAPLAN S. L., RUDOLPH A. M., GRUMBACH M. M., 1981. Hormone ontogeny in the ovine fetus. VII. Circulating luteinizing hormone and follicle-stimulating hormone in mid- and late gestation. Endocrinology, 108, 874880.

SPENCER G. S. G., GARSSEN G. J., HART I. E., 1983. A novel approach to growth promotion using auto-immunization against somatostatin. I. Effects of growth and hormone levels in lambs. Livest. Prod. Sci., 10, 25-37.

WALLACE A. L. C., STACY B. D., THORBURN G. D., 1973. Regulation of growth hormone secretion in the ovine fetus. J. Endocrinol., 58, 89-95.

ZAMBONI L., DE MARTINO C., 1967. Buffered picric acid formaldehyde : a new rapid fixative for electron microscopy. J. Cell Biol., 35, 148A. 